\title{
Improving the technology of chilled semi- finished products from Japanese mackerel with an extended shelf life
}

\section{Melhorando a tecnologia de produtos semiacabados resfriados de cavala japonesa com vida útil estendida}

\author{
Dementieva Natalia Valerievna1, Bogdanov Valeryi Dmitrievich* (D), Sakharova Olga \\ Valentenovna ${ }^{1}$, Fedoseeva Elena Vladimirovna ${ }^{1}$
}

${ }^{1}$ Far Eastern State Technical Fisheries University, Department Technology of Food Products, Vladivostok - Russia

*Corresponding author: Bogdanov Valeryi Dmitrievich, Far Eastern State Technical Fisheries University, Department Technology of Food Products, 52B Lugovaya St, Primorsky Region, 690600, Vladivostok - Russia, email: bogdanovvd@dgtru.ru

Cite as: Valerievna, D. N., Dmitrievich, B. V., Valentenovna, S. O., \& Vladimirovna, F. E. (2021). Improving the technology of chilled semi-finished products from Japanese mackerel with an extended shelf life. Brazilian Journal of Food Technology, 24, e2018263. https://doi.org/10.1590/1981-6723.26318

\begin{abstract}
One of the actual areas of processing the aquatic biological resources is the production of chilled fish semi-finished products, the most prepared for heat treatment. Such products have a very limited shelf life, because fish raw materials have high enzymatic activity. This research work aimed to improve the technology of chilled fish semi-finished products from Japanese mackerel with an extended shelf life. To achieve this goal, Japanese mackerel was injected with multicomponent salting media, containing food additives that slow down microbial contamination, have a bacteriostatic effect and assist in improving the organoleptic characteristics of the finished product. New receptions of salting multicomponent compositions provide faster salting and ripening of raw materials compared to the control sample. Salt concentration in fish, amine nitrogen and peroxide value were determined by titration methods. The total number of mesophilic aerobic and facultative anaerobic microorganisms (KMAFAnM) in fish semi-finished products was determined by identifying the number of grown colonies of microorganisms on nutrient media from agar. The treatment of Japanese mackerel with developed salting media, including moisture-retaining components, organic acids and flavoring additives with anti-bactericidal properties, improves the organoleptic characteristics of the finished product, promotes more salting and maturation of fish, as well as reducing the number of microorganisms (KMAFAnM). The increase in amine nitrogen content ranged from $1.4 \mathrm{~g} / \mathrm{kg}$ (at the beginning of the salting) to $1.55 \mathrm{~g} / \mathrm{kg}$ in the control and up to $3.05 \mathrm{~g} / \mathrm{kg}$ in the test samples by the end of the salting. Salt concentration in Japanese mackerel treated with control salting media amounted to $1.19 \%$, new developed salting media - from $2.84 \%$ to $3.17 \%$. The total abundance of microorganisms in Japanese mackerel was $2.0 \times 10^{2} \mathrm{CFU} / \mathrm{g}$, after salting it decreased to 0.1 to $3.0 \times 10^{1} \mathrm{CFU} / \mathrm{g}$ depending on the formulation of media for salting. According to the research results, the rational duration of the salting of Japanese mackerel, with new media for salting was 4 to $5 \mathrm{~h}$ at a temperature of $6^{\circ} \mathrm{C}$ to $8^{\circ} \mathrm{C}$. Along with the salting media developed by us, the use of modern packaging materials in the technology provided chilled culinary semi - finished products from Japanese mackerel with longer shelf life of up to 20 days at a temperature of $0{ }^{\circ} \mathrm{C}$ to $5{ }^{\circ} \mathrm{C}$, and humidity $95 \%$ to $98 \%$.
\end{abstract}

Keywords: Japanese mackerel; Salting media; Technology; Chilled semi-finished products; Shelf life; Packaging materials. 


\section{Resumo}

Um dos segmentos atuais de processamento dos recursos biológicos aquáticos é a produção de produtos semiacabados de peixe resfriado, os mais preparados para o tratamento térmico. Esses produtos têm uma vida útil muito limitada, porque as matérias-primas têm alta atividade enzimática. O objetivo deste trabalho de pesquisa foi melhorar a tecnologia de produtos semiacabados de cavalinha japonesa (japanese mackerel) resfriada com uma vida útil prolongada. Para atingir esse objetivo, a cavalinha foi injetada com uma salmoura de multicomponentes, contendo aditivos que diminuem a contaminação microbiana, têm um efeito bacteriostático e ajudam a melhorar as características organolépticas do produto acabado. Novas formulações de salmoura de múltiplos componentes permitem salga e maturação mais rápidas das matérias-primas em comparação com a amostra de controle. A concentração de sal nos peixes, amina nitrogenada e o valor de peróxido foram determinados por titulação. Contagem total de microrganismos mesofílicos aeróbicos e anaeróbicos facultativos (NMAFAnM) em produtos semiacabados de peixes foi determinada pela identificação do número de colônias de microrganismos em meios nutricionais do ágar. O tratamento do peixe cavalinha com as salmouras desenvolvidas, incluindo componentes que retem umidade, ácidos orgânicos e aditivos aromatizantes com propriedades antibactericidas, melhora as características organolépticas do produto acabado, promovem a salga e a maturação dos peixes, reduzindo o número de microrganismos (NMAFAnM). O toer de amina nitrogenada variou de $1,4 \mathrm{~g} / \mathrm{kg}$ (no início da salga) a 1,55 g/ $\mathrm{kg}$ no controle e até $3,05 \mathrm{~g} / \mathrm{kg}$ nas amostras de teste até o final da salga. A concentração de sal no peixe cavalinha tratado com salmoura foi de 1,19\% e com as novas formulações variou de $2,84 \%$ a 3,17\%. A contagem total de microrganismos no peixe cavalinha foi de $2,0 \times 10^{2} \mathrm{CFU} / g$, após a salga reduziu para 0,1 a 3,0 $\times 10^{1} \mathrm{CFU} / \mathrm{g}$, dependendo da formulação empregada. De acordo com os resultados da pesquisa, a duração ideal da salga do peixe cavalinha, com novos meios de salga, é de 4 a $5 \mathrm{~h}$ a uma temperatura de $6{ }^{\circ} \mathrm{C}$ a $8{ }^{\circ} \mathrm{C}$. Juntamente com os meios de salga desenvolvidos, o uso de novos materiais de embalagem permitem a obtenção de produtos culinários semiacabados de cavalinha com prazo de validade de até 20 dias a uma temperatura de $0{ }^{\circ} \mathrm{C}$ a $5{ }^{\circ} \mathrm{C}$, umidade $95 \%$ a $98 \%$.

Palavras-chave: Peixe cavalinha japonesa; Meio de salga; Tecnologia; Produtos semiacabados refrigerados; Prazo de validade; Materiais de embalagem.

\section{Introduction}

At present, one of the areas of processing of aquatic biological resources is the production of refrigerated semi-finished products, i.e., sliced or filleted fish, as much as possible prepared for heat treatment (Alfaro et al., 2013; Okpanachi et al., 2018). The need for this type of product is associated with the trends of healthy eating of the population, with the growing pace of life and limited time for cooking. Such products are currently represented in the Russian market mainly by semi-finished products from meat raw materials, which are in high demand among the population (Molchanova et al., 2013).

Similar products from fish are produced only in certain regions and its range is very limited (Bugakov et al., 2012; Nehamkin et al., 2015). This is probably related to the fact that chilled fish products due to higher enzymatic activity of muscle tissue which, spoil faster (Boland et al., 2013). The shelf life of chilled fish semi-finished products at a temperature of $0{ }^{\circ} \mathrm{C}$ to $4{ }^{\circ} \mathrm{C}$ is $24 \mathrm{~h}$; and vacuum packed - from five to 12 days (depending on the packaging materials). Taking into account the consumer's orientation towards natural healthy food, the demand for chilled semi-finished fish as much as possible prepared for posterior heat treatment from environmentally friendly raw materials with the addition of spices, kitchen herbs, and various marinades will continue to increase substantially (Pieniak et al., 2010; Zhang et al., 2016; Morales \& Higuchi, 2018). Therefore, there is a need to search for technological methods that increase the shelf life of such products.

In the production of fish semi-finished products short-term salting fish provides: the penetration, distribution and accumulation of salt components in fish; the state change of proteins; changing forms of water binding ties, water-binding ability and weight of fish; development of chemical and enzymatic processes with the formation of flavoring substances; a change of quantitative content and qualitative composition of microorganisms (Kaya \& Basturk, 2015; Topuz, 2016; Ucak \& Gökoğlu, 2017). Short- 
term fish salting is considered not only as a method of preserving the raw fish materials and finished products, but also as one of the methods of technological processing, which allows to modify the properties of the main raw materials for subsequent production of various types of products from it by using different types of heat treatment (Dimova et al., 2006; Blagonravova \& Gritsaenko, 2014). Dry, wet, and mixed salting is applied in the fishing industry. With dry salting, the fish are rubbed with table salt, laid in layers of fish then salt. During the salting process, the salt is hydrated by the water contained in the raw material, forming a concentrated brine and increasing the difference in osmotic pressures on the surface and inside the finished product. The formed brine partially diffuses into the product, and part of it drains, as a result of which the fish is dehydrated. The use of dry salting is limited in modern industrial processing. The main disadvantages of dry salting are that the product is salty and hard, the distribution of salt in the product is uneven and yield of products is low (Dimova et al., 2006; Blagonravova \& Gritsaenko, 2014). Wet salting or brining allows obtaining the products with a more even distribution of salt. It is carried out by immersing the fish in the brine, with the subsequent aging of the fish in it. The disadvantage of this method is that, at the end of the process, the finished product has increased humidity, and is not always suitable for long-term storage (Bogdanov \& Saltanova, 2005; Dimova et al., 2006; Blagonravova \& Gritsaenko, 2014). Modern technologies use the introduction of brines into raw fish materials by injection (syringing) followed by mechanical processing of raw materials, or by keeping the fish in the brine or outside it. In this case, the salting process has a diffusionosmotic nature, and its acceleration is achieved by using a combination of different physical and chemical methods. When salting the fish, salting substances and food additives are used, both for surface treatment of raw fish materials, and for preparing brines, marinades, and other types of multicomponent solutions of various technological purposes on their basis.

Brines used for injecting or holding raw fish materials in them are conditionally divided into several types. Simple brines consist of traditional salt substances - or sugar. These are «true solutions» with high kinetic and thermodynamic stability. Their use provides a yield of finished products of $75 \%$ to $100 \%$. Complex brines contain salting ingredients as well as food phosphates and protein preparations. These brines are suspensions due to the presence of insoluble protein preparations.

Multicomponent brines are complex disperse systems («true solution» + suspension + gel), which include high-molecular compounds (protein preparations, starches, food hydrocolloids) along with water-soluble substances (salting, flavoring substances, phosphates, dyes, etc.) (Schuldt et al., 2014). The most promising of the brines are multicomponent brines containing soy protein isolates, carrageenans, and native starches in addition to salting and phosphate. The prevailing preferential attitude towards these high-molecular substances is primarily due to their guaranteed biological safety, relative simplicity of technological use, high functional and technological properties, and market and economic accessibility (Smaoui et al., 2012; Amariei et al., 2016).

Therefore, the process of selection of types and quantities of ingredients for brine systems is an important issue that can significantly affect the organoleptic, physico-chemical, structural and mechanical characteristics, as well as the shelf life and yield of chilled fish semi-finished products.

The final goal of this research was to substantiate the technology of chilled fish semi-finished products from Japanese mackerel with a prolonged shelf life.

To achieve that goal the following tasks carried out:

- to develop recipes for salting media, the components of which will improve the organoleptic characteristics, prevent oxidative damage, slow down the development of microorganisms, and thereby ensure a longer storage of finished products;

- to study the influence of the method of salting and salting media on the degree of salting out, ripening, change in organoleptic and microbiological parameters of semi-finished products;

- to develop a technological scheme for the production of refrigerated semi-finished fish with prolonged shelf life. 


\section{Material and methods}

For the experimental study, frozen Japanese mackerel (Scomber japonicus) was used, which was purchased in the fishing port of Vladivostok (Russian Federation) at the Sigma Marine Technology Ltd. It was stored for 3 months at a temperature of $-25^{\circ} \mathrm{C}$.

Auxiliary materials were used for technological purposes: food grade salt; granulated sugar; ascorbic acid; mustard powder; carrageenan; dried rosemary; soy isolate; citric acid; coriander; lemongrass; black pepper ground; garlic; ground red pepper; thyme; lemon balm; a mixture of bell peppers; and ground cardamom. Auxiliary materials were purchased in the trade network of Vladivostok, Russian Federation. Their quality could meet the requirements of technical regulations of the Russian Federation. To prepare multicomponent brines, salt and sugar were dissolved in cold water. The resulting salt solution was sterilized for $25 \pm 5$ min at a temperature of $100 \pm 1.5^{\circ} \mathrm{C}$.

After heat treatment, the brine was cooled to a temperature of $4{ }^{\circ} \mathrm{C}$ to $5{ }^{\circ} \mathrm{C}$. On the basis of a standard brine, the remaining multicomponent brines were prepared, introducing the remaining components into it according to the recipe, thoroughly mixing. The brine temperature should not exceed $4{ }^{\circ} \mathrm{C}$. The prepared brine was held for 20 to $30 \mathrm{~min}$ before salting. Ready brines were stable during the day at a temperature of 0 ${ }^{\circ} \mathrm{C}$ to $4{ }^{\circ} \mathrm{C}$.

The Japanese mackerel was cut into fillets. The brines were injected into the muscle tissue with the help of nickel-plated hollow perforated needles of 150 to $160 \mathrm{~mm}$ length, $1,5 \mathrm{~mm}$ inner diameter, and $3 \mathrm{~mm}$ outer diameter, and a needle insertion pitch of 10 to $20 \mathrm{~mm}$. The amount of brine introduced was $20 \%$ of the weight of the product. After syringing the fish with brine, it was kept at a temperature of $6{ }^{\circ} \mathrm{C}$ to $8{ }^{\circ} \mathrm{C}$ for $5 \mathrm{~h}$. The degree of salting was determined by the change in the concentration of sodium chloride in the raw material. The maturation of fish was estimated by the increase of amine nitrogen content, which shows the degree of hydrolysis of proteins in the muscle tissue of fish. The influence of the duration of salting and the formulation of the salting mixture on the change in the organoleptic and microbiological parameters of the semi-finished products were also determined.

In the production of semi-finished products, Japanese mackerel fillet was preliminary salted in the curing media according to recipes $1,2,3$. The control was a curing mixture consisting of water, salt, and sugar. Composition of curing media (\%): - control: water (83) - salt (14) - sugar - (3); -recipe 1 (\%): water (83) salt (14) - sugar - (3) - trisodium pyrophosphate - (1) - ascorbic acid - (0.5) - mustard (0.1); -recipe $2(\%)$ : water (83) - salt (14) - sugar- (3) - carrageenan - (1) - tartaric acid - (0.5) - rosemary - (0.2); -recipe $3(\%)$ : water (83) - salt (14) - sugar - (3) - soy protein - (4) - citric acid - (0.5) - coriander - (0.2).

When developing the formulations of multicomponent brines, the research team was guided by functional and technological properties, food additives used and recommended standards for their use in brines (Kolodyaznaya, Demchenko, 2010; Stepanenko et al., 2016).

During the Japanese mackerel aging, after injecting with brine, the change in the organoleptic parameters of the fish was determined depending on the duration of its aging in the salt.

Fish, at intervals of $1.5 ; 3.5 \mathrm{~h}$ were cooked on steam for $20 \mathrm{~min}$, then cooled to $35^{\circ} \mathrm{C}$ and tasting performed.

Determination of the salting media $\mathrm{pH}$ was done by potentiometric method using a potentiometer (Model IPL-101-1, Grand company, St. Petersburg).

To determine salt content of the fish, an argentometric method for the determination of table salt was used. The method is based on the interaction of sodium chloride with silver nitrate in the presence of potassium chromate with the formation of a red precipitate - silver chromate. A piece of the test sample ( 2 to $5 \mathrm{~g}$ ), weighed with an absolute error of not more than $0.01 \mathrm{~g}$, was placed in a volumetric flask with a capacity of 200 to $250 \mathrm{~cm}^{3}$ and poured into $3 / 4$ of the volume with distilled water, heated to $60{ }^{\circ} \mathrm{C}$. The contents of the flask were allowed to stand for 15 to $20 \mathrm{~min}$, occasionally shaking vigorously. Upon 
completion of the infusion, the liquid in the flask was cooled to room temperature; the volume was brought up to the mark with water. 10 to $25 \mathrm{~cm}^{3}$ of the filtrate were taken into two conical flasks and titrated with a solution of silver nitrate $\left(0.1 \mathrm{~mol} / \mathrm{dm}^{3}\right)$ in the presence of 3 to 4 drops of a potassium chromate solution $\left(100 \mathrm{~g} / \mathrm{dm}^{3}\right)$ until a reddish-brown color was obtained. Mass fraction of sodium chloride in percent was calculated by the Formula 1:

$X=\frac{K \cdot 0.00585 \cdot V \cdot V_{1} \cdot 100}{V_{2} \cdot m}$

where $\mathrm{V}$ - volume of water extract in a volumetric flask, $\mathrm{cm}^{3} ; \mathrm{V}_{1}$ - volume of silver nitrate solution $(0.1$ $\mathrm{mol} / \mathrm{dm}^{3}$ ) spent on titration of the test solution, $\mathrm{cm}^{3} ; \mathrm{V}_{2}$ - volume of water extract taken for titration, $\mathrm{cm}^{3} ; \mathrm{m}$ - piece of the test sample, $\Gamma ; 0.00585$ - the amount of sodium chloride corresponding to $1 \mathrm{~cm}^{3}$ of a solution of $0.1 \mathrm{~mol} / \mathrm{dm}^{3}$ of silver nitrate, $\mathrm{g}$; $\mathrm{K}$ - conversion factor for an exact solution of $0.1 \mathrm{~mol} / \mathrm{dm}^{3}$ of silver nitrate.

The degree of hydrolysis of Japanese mackerel proteins during its aging in multicomponent brines was estimated by the accumulation of amino nitrogen, which was determined by the method of formal titration (Kolodyaznaya \& Demchenko, 2010; Stepanenko et al., 2016). A portion of minced fish no more than $4 \mathrm{~g}$ was transferred into a 200 to $250 \mathrm{ml}$ volumetric flask and distilled water was poured into $1 / 3$ of the flask. The contents of the flask were mixed and placed in a boiling water bath for five min. After that, the flask contents were cooled and brought to the mark with distilled water. The resulting solution was filtered through a pleated filter. Titration was carried out in parallel in three conical flasks with a capacity of $300 \mathrm{ml}$. Indicators were pre-prepared. To prepare indicator No. $1,0.05 \mathrm{~g}$ of methyl red and $0.05 \mathrm{~g}$ of methylene blue were dissolved in $100 \mathrm{ml}$ of ethyl alcohol. To prepare indicator No. 2, $0.05 \mathrm{~g}$ of thymol blue was dissolved in 50 $\mathrm{ml}$ of $50 \%$ ethyl alcohol, as well as $0.15 \mathrm{~g}$ of phenolphthalein was dissolved in $150 \mathrm{ml}$ of $50 \%$ ethyl alcohol. The resulting solutions were mixed. To determine the acidity of the filtrate, 20 to $25 \mathrm{ml}$ of the filtrate was pipetted into a $300 \mathrm{ml}$ conical flask, $0.4 \mathrm{ml}$ of indicator No. 1 and $1 \mathrm{ml}$ of indicator No. 2 were added. Then we titrated $0.2 \mathrm{~N}$ with $\mathrm{NaOH}$ solution. Titration was determined by the change from green to blue. To determine amine nitrogen, 20 to $25 \mathrm{ml}$ of the filtrate was pipetted into the flask and $10 \mathrm{ml}$ of formalin and 1 $\mathrm{ml}$ of indicator No. 2 were added. Then $0.2 \mathrm{~N}$ was titrated with $\mathrm{NaOH}$ solution until the yellow color of the solution turned purple. To determine the acidity of formalin, 20 to $25 \mathrm{ml}$ of distilled water was measured into the flask with a pipette (as much as was taken in one and two flasks of the filtrate), $10 \mathrm{ml}$ of formalin and 1 $\mathrm{ml}$ of indicator No. 2 were added. Then $0.2 \mathrm{~N}$ was titrated with $\mathrm{NaOH}$ solution until the yellow color of the solution turned purple. The amount of amino nitrogen in $\mathrm{mg} \%$ is calculated by the Formula 2:

$\mathrm{X}_{\mathrm{mg} \%}=\frac{(B-A-C) * K^{*} 2,8^{*} V k^{*} 100}{g^{*} V \text { pipette }}$,

where, $\mathrm{g}$ - mass of piece of test sample, g; 2.8 - amount of nitrogen, $\mathrm{mg}$ that was equivalent to $1 \mathrm{ml}$ of 0.2 $\mathrm{N}$ solution $\mathrm{NaOH}$; A, B, C -titration results for flasks No. 1, No. 2, No. 3, ml; K - correction factor of $0.2 \mathrm{~N}$ solution $\mathrm{NaOH} ; \mathrm{V} k$-the volume of the flask in which the sample was dissolved, $\mathrm{g} ; \mathrm{V}_{\text {pipette }}-$ filtrate volume for testing.

The peroxide number of Japanese mackerel lipids was determined by the titrimetric method. The method is based on the ability of peroxides in an acidic environment to oxidize potassium iodide with the release of molecular iodine, which is then determined by titration with a sodium thiosulfate solution, using a starch as an indicator. About $0.8 \mathrm{~g}$ of fat extracted from Japanese mackerel, weighed with an accuracy of not more than $0.0002 \mathrm{~g}$, was added to a conical flask with a ground stopper, $10 \mathrm{~cm}^{3}$ of chloroform and glacial acetic acid were added. $0.5 \mathrm{~cm}^{3}$ of a saturated freshly prepared potassium iodide solution was quickly added. The flask was closed with a stopper, the contents of the flask were mixed by rotational movements and put in a dark place for three min. Then, $100 \mathrm{~cm}^{3}$ of distilled water was poured into the flask, to which $1 \mathrm{~cm}^{3}$ of starch solution with a mass fraction of $1 \%$ was added in preliminary. It was titrated with a sodium thiosulfate solution with a molar concentration of $0.01 \mathrm{~mol} / \mathrm{dm}^{3}$ until the blue color disappeared. To check the purity of the reagents, a control determination (without fat) was performed. Reagents were considered suitable for 
analysis if no more than $0.07 \mathrm{~cm}^{3}$ of sodium thiosulfate solution with a molar concentration of $0.01 \mathrm{~mol} / \mathrm{dm}^{3}$ went into the control determination. The peroxide value $\left(\% \mathrm{~J}_{2}\right)$ was calculated by the Formula 3 :

$X_{1}=\left[\left(V-V_{1}\right) K \cdot 0.00127 \cdot 100\right] / m$,

where $V$ - the volume of the sodium thiosulfate solution with a molar concentration of $0.01 \mathrm{~mol} / \mathrm{dm}^{3}$, spent on titration during the main experiment with a portion of fat, $\mathrm{cm}^{3} ; V_{l}$ - volume $\left(0.01 \mathrm{~mol} / \mathrm{dm}^{3}\right)$ of sodium thiosulfate solution used for titration during the control experiment (without fat), $\mathrm{cm}^{3} ; K$ - correction factor for sodium thiosulfate solution to be converted to the exact $\left(0.01 \mathrm{~mol} / \mathrm{dm}^{3}\right)$ solution; 0.00127 - the amount of grams of iodine equivalent to $1 \mathrm{~cm}^{3}\left(0.01 \mathrm{~mol} / \mathrm{dm}^{3}\right)$ of sodium thiosulfate solution; $m$ - mass of piece of tested fat, $\mathrm{g}$.

The organoleptic assessment of the quality of the semi-finished products was determined in accordance with the terminology of the description of characters, which became most common in practice and the results of tasting meetings (Kim et al., 2014).

To conduct tastings, an expert commission was established, consisting of a working and expert groups. The working group consisted of a leader, technical staff, and an expert on evaluated products. The staff members were involved in compiling the questionnaires, interviewing the experts and processing the results. There were two staff members. The expert group included qualified fish processing technologists (seven members) who underwent special training as tasters of fish products. They previously developed and prepared questionnaires to assess the organoleptic quality indicators of the finished product. The decision on the quality of the products was based on the results of evaluations of experts in questionnaires. The decision was considered adopted if at least $2 / 3$ of the experts voted for it.

Vacuum packaging of semifinished products was carried out in Darfresh (R) thermoforming films (Cryovas, Sweden). This type of packaging was intended for use in "Heat \& Serve" microwave ovens (Preheat and serve without having to open or puncture the film). The packaging film had a width of $468 \mathrm{~mm}$, a thickness of $150 \mu \mathrm{m}$. The packaging had high oxygen impermeability (oxygen permeability of not more than $\left.5 \mathrm{~cm}^{3} / \mathrm{m}^{2} / 24 \mathrm{~h}\right)$, high impact resistance $\left(90 \mathrm{~kJ} / \mathrm{m}^{2}\right)$, low moisture absorption coefficient, did not contain chlorine. Then the semi-finished products were cooled to a temperature in the center of the product no higher than $3{ }^{\circ} \mathrm{C}$ and stored in a refrigerator at a temperature of $0{ }^{\circ} \mathrm{C}$ to $5{ }^{\circ} \mathrm{C}$ and an air humidity of $95 \%$ to $98 \%$ for 25 days. During this time, samples were taken to determine the microbiological and organoleptic characteristics of the finished product.

The total abundance of the microorganisms (KMAFAnM) in fish semi-finished products was determined by adding more data; in which a micro method could complete the number of grown colonies of microorganisms on nutrient media from agar (European Union, 2007). The method is based on the ability of mesophilic aerobes and facultative anaerobes to grow on nutrient media of a certain composition at a temperature of $30^{\circ} \mathrm{C}$ with the formation of colonies, visible with a 2-fold increase. To determine the number of mesophilic bacteria, one should choose the dilution, when sowing which on the plates grows at least 30 and not more than 300 colonies. From each sample, in-depth inoculation was made on two parallel Petri cups from two to three consecutive dilutions in an amount of $1.0 \mathrm{ml}$ using $2 \%$ agar prepared from dry nutrient agar. The cups were poured with molten and cooled to $45^{\circ} \mathrm{C}$ agar immediately after making the material. After the agar solidified, the inoculated cups were placed upside down in an incubator, incubated at $30^{\circ} \mathrm{C}$ for $72 \mathrm{~h}$. The number of colonies was counted on each of the seeded cups. Colony counting on cups was performed using a bacterial colony counting device or a magnifier. When counting, the following rules were followed: if a small number of colonies grew on a cup, approximately 100, all colonies were counted; if the colonies were evenly distributed and their number was measured in several hundred (200-300 colonies), colonies were counted on at least $1 / 3$ of the area of the cup. In these cases, the bottom of the cup was divided into six sectors with a pencil and the colonies in three sectors were counted. Then, a recount was made for 
the entire area of the cup: the average number of colonies in the area of one sector was calculated and the obtained number of colonies in one sector was multiplied by six.

Images of microorganisms in salted media were obtained using a LevenhukD70L digital microscope with magnifications from 40 to 1600 times.

For data analysis, Statistics 6.0 (StatSoft Inc.) and Microsoft Excel 2007 were used and a confidence level of 0.95 was considered. Polynomial regression was used to describe the changes in studied parameters and the r-squared R2 used to assess models' goodness of fit.

The numerical values indicated in the tables and graphs are arithmetic mean, whose reliability $(\mathrm{P})=0.95$, confidence interval $(\Delta) \pm 10 \%$.

\section{Results and discussion}

For Japanese mackerel salting, we developed recipes of salting media, which included components that improved the organoleptic characteristics of refrigerated semi-finished products and ensured longer storage of finished products.

When formulating salting media multicomponent brines, three main criteria were followed:

- the composition of the salting mixture must include water-retaining agents with protein-restoring properties that will significantly improve the quality characteristics of the product being developed and minimize the loss of unbound water in the semi-finished product, which will inhibit microbial contamination;

- salting mixtures should contain organic acids, which have a pronounced bacteriostatic effect, which will significantly reduce product contamination and prolong storage time;

- flavor and aromatic additives in the composition of salting mixtures should have multifunctionality, i.e., improve organoleptic charcateristics in combination with antifungal and antimicrobial effect, which will also provide an additional barrier for pathogenic and opportunistic microflora (Elgayyar et al., 2001; Falowo et al., 2014; Fatma Ali et al., 2018).

Thus, the composition of multicomponent brines, in addition to basic (salt and sugar) components, includes the components that will improve the organoleptic parameters, prevent oxidative damage, slow down the development of microorganisms, and thereby ensure a longer storage of finished products (Georgantelis et al., 2007; Estévez. et al., 2007; Gheisari \& Ranjbar, 2012). As a control, a standard brine including sodium chloride and sugar was used (Table 1).

Table 1. Recipes of multicomponent brines for Japanese mackerel.

\begin{tabular}{ccccc}
\hline Brine components & \multicolumn{3}{c}{ Recommended application rates [\%] } \\
\cline { 2 - 5 } & Control & Recipe 1 & Recipe 2 & Recipe 3 \\
\hline Sodium chloride & 14 & 14 & 14 & 14 \\
\hline Sugar & 3 & 3 & 3 & 3 \\
\hline Trisodium pyrophosphate $\left(\mathrm{Na}_{3} \mathrm{HP}_{2} \mathrm{O}_{7}\right)$ & - & 1 & - & - \\
\hline Carrageenan & - & - & 1 & - \\
\hline Soy isolated protein $(\mathrm{SUPRO}-595)$ & - & - & - & - \\
\hline Ascorbic acid & - & 0,05 & - & - \\
\hline Wine acid & - & - & 0,05 & - \\
\hline Lemon acid & - & - & - & - \\
\hline Mustard & - & 0,1 & - & - \\
\hline Rosemary & - & - & 0,2 & - \\
\hline Coriander & - & - & 0,2 \\
\hline
\end{tabular}


The dependence of the change in the content of sodium chloride in Japanese mackerel on the salting for the selected formulation is shown in Figure 1. Salt concentration in the fish was $0.68 \%$ immediately after the introduction of brine into the muscular tissue of Japanese mackerel. This mackerel injected with multicomponent brines was salted faster than in control brine. After $1.5 \mathrm{~h}$, the salt concentration in the Japanese mackerel injected with control brine was $1.13 \%$, and in the fish samples injected with multicomponent brines, the salt concentration ranged from $2.61 \%$ to $3.06 \%$. The highest rate of rejection in a sample of Japanese mackerel was injected multi-component brine, cooked according to the recipe No. 3, which included soy isolated protein and citric acid. This higher rate of salting out in multicomponent brines was probably due to the breakdown of proteins and loosening of the structure of muscle fibers under the influence of phosphates, soy protein isolates, carrageenans, and organic acids. (Dixon et al., 1987; Pohlman et al., 2009).

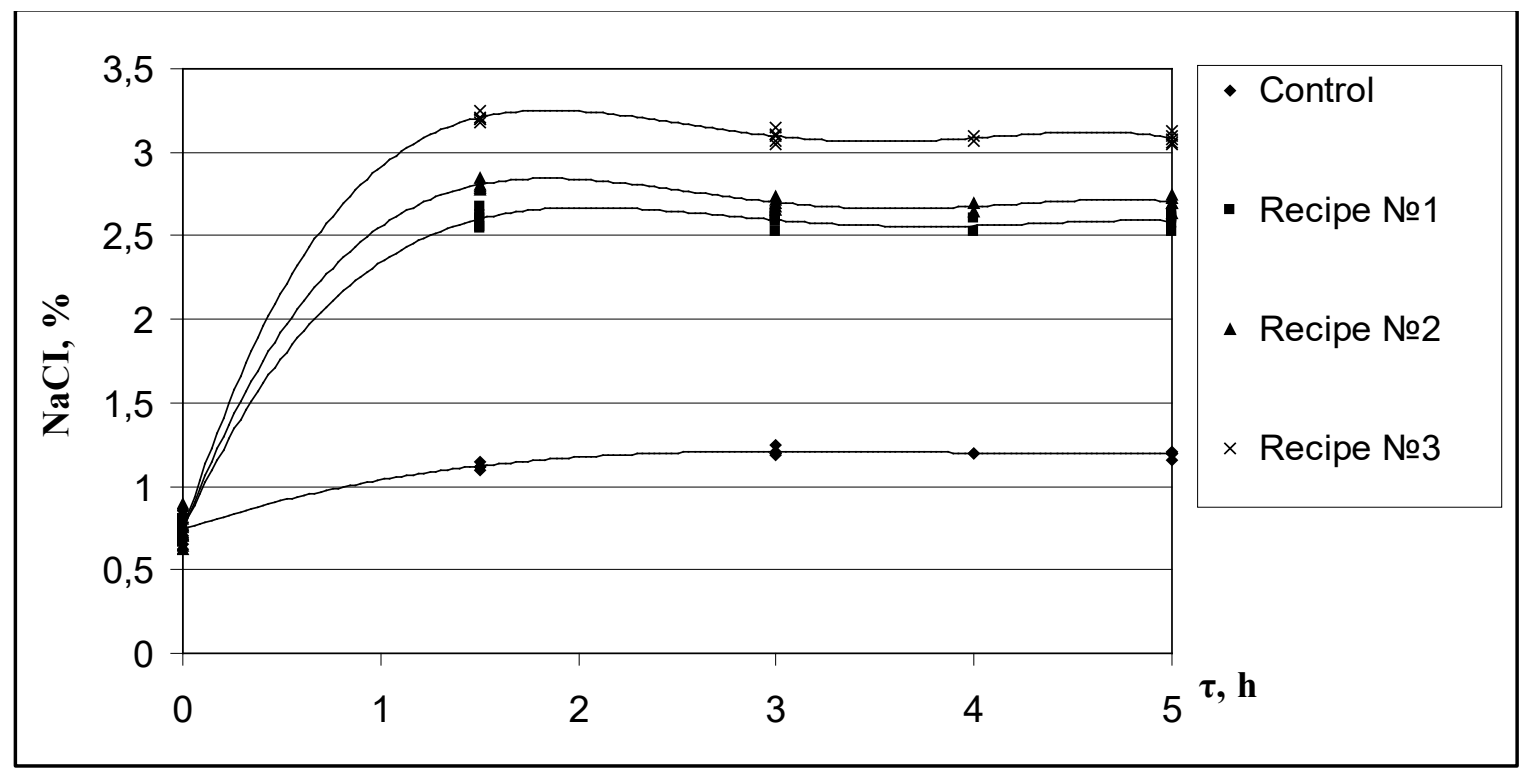

Figure 1. Change in the content of sodium chloride $[\mathrm{NaCl}]$ in Japanese mackerel with the duration of salting and the selected formulation (control: $y=-0.0002 x^{4}+0.0109 x^{3}-0.1112 x^{2}+0.3961 x+0.742, R^{2}=0,9551$; recipe $N^{0} 1: y=-$ $0.0177 \mathrm{x}^{4}+0.2518 \mathrm{x}^{3}-1.2697 \mathrm{x}^{2}+2.6419 \mathrm{x}+0.734, \mathrm{R}^{2}=0.9964 ;$ recipe $\mathrm{N}^{\circ} 2: \mathrm{y}=-0.0247 \mathrm{x}^{4}+0.3363 \mathrm{x}^{3}-1.6101 \mathrm{x}^{2}+$ $3.1299 x+0.724, R^{2}=0,19958$; recipe $\left.N^{0} 3: y=-0.0313 x^{4}+0.4168 x^{3}-1.9599 x^{2}+3.7651 x+0.722, R^{2}=0.9988\right)$.

With the subsequent curing of the Japanese mackerel samples in the salt for a further 3 to $5 \mathrm{~h}$, the degree of salting out of the brine formulation was directly related. After $5 \mathrm{~h}$ of salting, the salt concentration in the Japanese mackerel injected with control salting media was $1.19 \%$ whereas in fillets, injected with multicomponent salting media - it ranged from $2.84 \%$ to $3.17 \%$.

Notably, after injecting the Japanese mackerel with brine, swelling of the muscle tissue was noted, and throughout the salting time a separation of the injected brine did not occur, which again could be confirmed that the muscular tissue of Japanese mackerel had a high water-binding capacity (Naresh \& Nayak, 2017).

During Japanese mackerel curing after brine injection, the accumulation of amine nitrogen was monitored, according to the increment of which the degree of ripening of the fish was determined, depending on the duration of aging and the formulation of the salting mixture (Figure 2). 


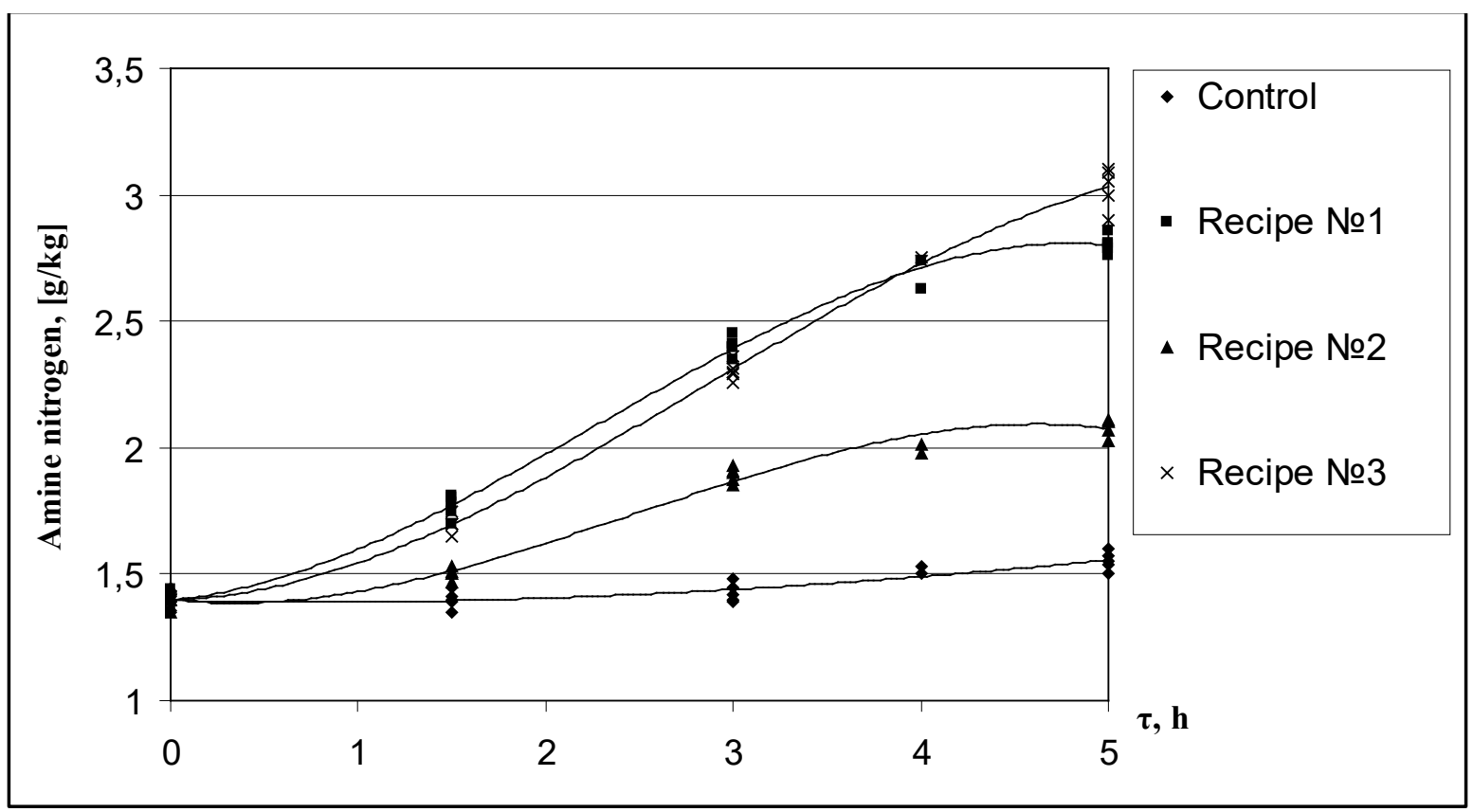

Figure 2. Change in the content of amine nitrogen in Japanese mackerel with the duration of salting and the selected formulation (control: $y=-0.0004 \mathrm{x}^{3}+0.0123 \mathrm{x}^{2}-0.0189 \mathrm{x}+1.3971, \mathrm{R}^{2}=0,7986$; recipe $\mathrm{N}^{\mathrm{o}} 1: \mathrm{y}=-0.0225 \mathrm{x}^{3}+0.1547 \mathrm{x}^{2}$ $+0.0695 x+1.3968, R^{2}=0,9954$; recipe $N^{0} 2: y=-0.018 x^{3}+0.134 x^{2}-0.0842 x+1.3994, R^{2}=0.9842$; recipe $N^{0} 3: y=$ $\left.-0.017 \mathrm{x}^{3}+0.1471 \mathrm{x}^{2}+0.0162 \mathrm{x}+1.3988, \mathrm{R}^{2}=0.9955\right)$.

The results of the rate showed that the rate and degree of ripening of Japanese mackerel directly depend upon the formulation of saline brine. The amount of amine nitrogen immediately after injection was $0.7 \mathrm{~g} / \mathrm{kg}$ of fish muscle tissue. The greatest increase in amine nitrogen concentration was measured in Japanese mackerel injected with salting media, prepared according to recipe No. 3, which included soy protein isolate, citric acid, and coriander. The increase in amine nitrogen was from $1.4 \pm 0.1 \mathrm{~g} / \mathrm{kg}$ (immediately after the introduction of the salting media) to $3.05 \pm 0.1 \mathrm{~g} / \mathrm{kg}$ by the end of the salting. The less intensive increase of amine nitrogen occurred in the control sample from $1.4 \pm 0.1 \mathrm{~g} / \mathrm{kg}$ to $1.55 \pm 0.1 \mathrm{~g} / \mathrm{kg}$.

The effects of the components of the developed curing medium on changes occurring in the lipids of Japanese mackerel also were investigated. The peroxide value in fish before salting was $0.01 \pm 0,005 \% \mathrm{I}_{2}$; but at the end of the salting process, the peroxide number in the control sample increased to $0.02 \pm 0.005 \% \mathrm{I}$; it remained at the same level $0.01 \%$ in the newly developed salting media. The injection of Japanese mackerel with multicomponent brines positively influences the organoleptic characteristics of raw materials. In the process of curing, the color of the fish improved, lightening of the muscular tissue of the Japanese mackerel from the dark beige with a brownish hue in the control sample to light cream after $5 \mathrm{~h}$ of soaking took place. In the process of salting the fish acquires a pleasant smell from brine compositions and spices. Consistency became more juicy and tender (Table 2). With further salting, the consistency was compacted, but remained juicy, the fibrousness of the muscle tissue disappeared. The taste became pleasant, depending on the formula with more or less pronounced sourness and with a hint of spices. Even in a control sample, with only salt and sugar in the brine composition, by the end of salting the fibrous tissue sensation disappeared, juiciness appeared, and the aftertaste of a small bitterness disappeared. According to the results of organoleptic indices, it was possible to recommend the time of aging of Japanese mackerel salting injected with salting media for four to $5 \mathrm{~h}$. According to the technical regulations of Eurasian Economic Union (EAEU) on safety of fish and fish products, the number of mesophilic aerobic and facultative anaerobic microorganisms (KMAFAnM) in refrigerated fish semi-finished products should not exceed $1 \times 10^{4} \mathrm{CFU} / \mathrm{g}$ (Eurasian Economic Union, 2017). A choice for a rational method for processing the semi-finished products was to study the change in the microbiological background, depending on the duration of the fish aging after injecting it with brines. The abundance of KMAFAnM in 
Japanese mackerel before injecting it with brine was $2.0 \times 10^{2} \mathrm{CFU} / \mathrm{g}$. The changes in KMAFAnM of Japanese mackerel depending on the duration of salting and the formulation of the salting mixture are depicted in Figure 3. The conducted studies showed intensive growth of KMAFAnM in the first $1.5 \mathrm{~h}$ of salting, followed by a decrease in the total number of microorganisms during aging was observed. More intensively, the microorganisms "died off" in samples injected with salting media. The total number of microorganisms in Japanese mackerel before salting was $2.0 \times 10^{2} \mathrm{CFU} / \mathrm{g}$, after salting it decreased and varied not exceed $3.0 \mathrm{x}$ $10^{1} \mathrm{CFU} / \mathrm{g}$. The microorganisms contained in the muscle tissue of fish and brine were characterized by a different sensitivities to table salt. Non-saline microorganisms (non-spore-forming gram-negative bacilli: Proteus, coliform bacteria (CB), (Pseudomonas in italics), were sensitive to the effect of table salt, in the brine. However, the salt-tolerant microorganisms persisted; some of them were able to adapt and start to multiply intensely, for example, lactic acid bacteria or micrococci (Dabrowski et al., 2002). Supposedly, the growth of KMAFAnM occurred in the first $1.5 \mathrm{~h}$ of aging in salting. Important factor in the process of salting is the maintenance of low temperatures, which significantly limits the multiplication of mesophilic microorganisms. The most effective temperature was $6-9{ }^{\circ} \mathrm{C}$, at which the development of mesophilic microorganisms was suppressed, the physical and chemical processes took place in salting proceed normally, and the vital activity of the beneficial microflora was activated (Dabrowski et al., 2002). Lactic acid bacteria (LAB) and micrococci could form a useful microflora of brines, as our studies showed (Figure 4) (Dabrowski et al., 2002; Françoise, 2010). LAB and micrococci also had antagonistic action against putrefactive bacteria. As a result of the activity of useful microorganisms, the $\mathrm{pH}$ of brines and muscle tissue of fish gradually decreased to 5.3 to 5.8, i.e., the reaction of the medium ceases to be optimal for bacteria splitting the protein, which could lead to a decrease in the total microbial number (KMAFAnM) under further aging of fish in salting. Thus, with salting, the following protective factors took place: concentration of table salt; reduced temperature; and microbial antagonism, which could ensure a reduction in the total microbial number in semi-finished products. A more intensive decrease for KMAFAnM in samples of Japanese mackerel injected with multicomponent brines as compared to the control was due to the fact that in addition to the above factors, there was a more intensive decrease in the $\mathrm{pH}$ of the brines, since organic acids were added to their formulations.

Table 2. Organoleptic parameters of Japanese mackerel depending on the duration of salting and the selected recipes.

\begin{tabular}{|c|c|c|c|c|}
\hline $\begin{array}{c}\text { Mixtures or Brines } \\
\text { instead }\end{array}$ & Colour & Smell & Consistency & Taste \\
\hline \multicolumn{5}{|l|}{$1.5 \mathrm{~h}$ aging time } \\
\hline Control & $\begin{array}{l}\text { Dark beige with a } \\
\text { brownish tinge }\end{array}$ & $\begin{array}{l}\text { Characteristic of } \\
\text { this type of fish, } \\
\text { pronounced }\end{array}$ & $\begin{array}{l}\text { Tough, } \\
\text { dryish, fibrous }\end{array}$ & $\begin{array}{l}\text { Characteristic of this } \\
\text { type of fish, with a } \\
\text { little bitterness }\end{array}$ \\
\hline Recipe No.1 & $\begin{array}{l}\text { Dark beige with a } \\
\text { brownish tinge }\end{array}$ & $\begin{array}{l}\text { Characteristic of } \\
\text { this type of fish }\end{array}$ & $\begin{array}{l}\text { Delicate, juicy, } \\
\text { less fibrous }\end{array}$ & $\begin{array}{l}\text { Characteristic of this } \\
\text { type of fish, with a } \\
\text { little acidity }\end{array}$ \\
\hline Recipe No.2 & $\begin{array}{l}\text { Dark beige with a } \\
\text { brownish tinge }\end{array}$ & $\begin{array}{l}\text { Fish, not } \\
\text { pronounced }\end{array}$ & $\begin{array}{l}\text { Delicate, very } \\
\text { juicy, not fibrous }\end{array}$ & $\begin{array}{l}\text { Characteristic of this } \\
\text { type of fish, with } \\
\text { pronounced acidity }\end{array}$ \\
\hline Recipe No.3 & $\begin{array}{l}\text { Dark beige with a } \\
\text { brownish tinge }\end{array}$ & $\begin{array}{l}\text { Fish, not } \\
\text { pronounced }\end{array}$ & $\begin{array}{l}\text { Thick, } \\
\text { juicy, not fibrous }\end{array}$ & $\begin{array}{l}\text { Characteristic of this } \\
\text { type of fish, with a } \\
\text { little acidity }\end{array}$ \\
\hline \multicolumn{5}{|l|}{$3 \mathrm{~h}$ aging time } \\
\hline Control & $\begin{array}{l}\text { Dark beige with a } \\
\text { brownish tinge }\end{array}$ & $\begin{array}{l}\text { Fish, not } \\
\text { pronounced }\end{array}$ & $\begin{array}{l}\text { Dense, rather dry, } \\
\text { less fibrous }\end{array}$ & $\begin{array}{l}\text { Characteristic of this } \\
\text { type of fish, with a } \\
\text { little bitterness }\end{array}$ \\
\hline Recipe No.1 & Light beige & $\begin{array}{l}\text { Fish, with a hint } \\
\text { of spiciness }\end{array}$ & $\begin{array}{l}\text { Delicate, very juicy, } \\
\text { not fibrous }\end{array}$ & $\begin{array}{l}\text { Characteristic of this } \\
\text { type of fish, with a } \\
\text { little acidity and } \\
\text { pungent taste }\end{array}$ \\
\hline
\end{tabular}


Table 2. Continued...

\begin{tabular}{|c|c|c|c|c|}
\hline $\begin{array}{c}\text { Mixtures or Brines } \\
\text { instead }\end{array}$ & Colour & Smell & Consistency & Taste \\
\hline Recipe No.2 & Light beige & $\begin{array}{l}\text { Fish, with a hint } \\
\text { of spiciness }\end{array}$ & $\begin{array}{l}\text { Delicate, very juicy, } \\
\text { not fibrous }\end{array}$ & $\begin{array}{l}\text { Characteristic of this } \\
\text { type of fish, with a } \\
\text { pronounced acidity, } \\
\text { with a hint of } \\
\text { spiciness }\end{array}$ \\
\hline Recipe No.3 & Light beige & $\begin{array}{l}\text { Fish, with a hint } \\
\text { of spiciness }\end{array}$ & $\begin{array}{l}\text { Plain, juicy, not } \\
\text { fibrous }\end{array}$ & $\begin{array}{l}\text { Characteristic of this } \\
\text { type of fish, with a } \\
\text { little acidity, with a } \\
\text { hint of spiciness }\end{array}$ \\
\hline \multicolumn{5}{|l|}{$5 \mathrm{~h}$ aging time } \\
\hline Control & Light beige & $\begin{array}{l}\text { Lightly salted } \\
\text { fish }\end{array}$ & $\begin{array}{l}\text { Dense, juicy, not } \\
\text { fibrous }\end{array}$ & $\begin{array}{l}\text { Characteristic of this } \\
\text { type of fish, without } \\
\text { bitterness }\end{array}$ \\
\hline Recipe No.1 & Light cream & $\begin{array}{l}\text { Marinated fish, } \\
\text { with a hint of } \\
\text { spiciness }\end{array}$ & $\begin{array}{l}\text { Plain, juicy, not } \\
\text { fibrous }\end{array}$ & $\begin{array}{l}\text { Characteristic of this } \\
\text { type of fish, with a } \\
\text { little acidity and } \\
\text { pungent taste }\end{array}$ \\
\hline Recipe No.2 & Light cream & $\begin{array}{l}\text { Marinated fish, } \\
\text { with a hint of } \\
\text { spiciness }\end{array}$ & $\begin{array}{l}\text { Plain, juicy, not } \\
\text { fibrous }\end{array}$ & $\begin{array}{l}\text { Characteristic of this } \\
\text { type of fish, with a } \\
\text { pronounced acidity, } \\
\text { with a hint of } \\
\text { spiciness }\end{array}$ \\
\hline Recipe No.3 & Light cream & $\begin{array}{l}\text { Marinated fish, } \\
\text { with a hint of } \\
\text { spiciness }\end{array}$ & $\begin{array}{l}\text { Plain, juicy, not } \\
\text { fibrous }\end{array}$ & $\begin{array}{l}\text { Characteristic of this } \\
\text { type of fish, with a } \\
\text { little acidity, with a } \\
\text { hint of spiciness }\end{array}$ \\
\hline
\end{tabular}

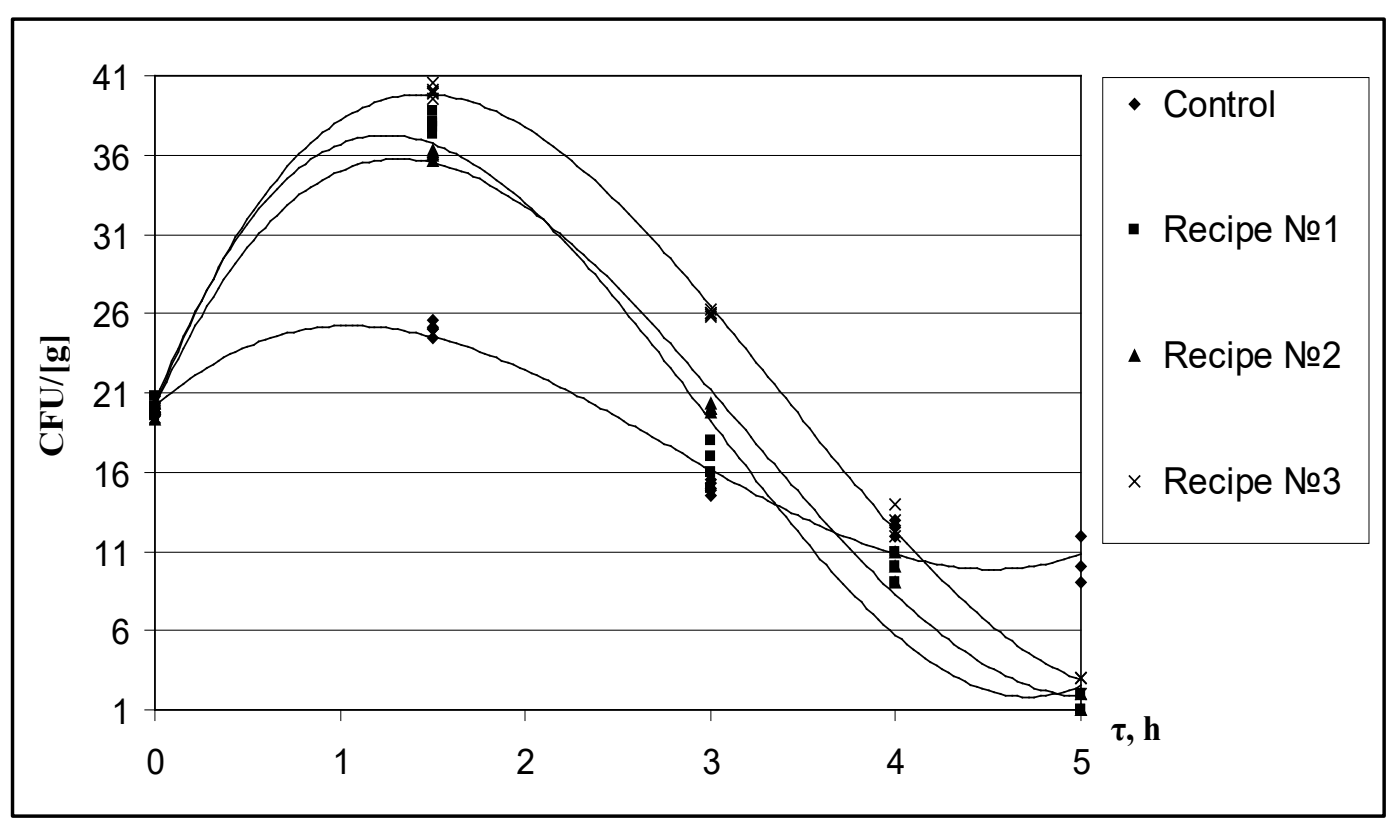

Figure 3. Change in NMAFAnM (in $[\mathrm{CFU} / \mathrm{g}]$ ) of Japanese mackerel after injection with the duration of salting and the formulation of the salting mixture (control: $y=0.7353 \mathrm{x}^{3}-6.1509 \mathrm{x}^{2}+10.513 \mathrm{x}+20.113, \mathrm{R}^{2}=0.958$; recipe $\mathrm{N}^{\mathrm{o}} 1$ : $\mathrm{y}$ $=1.6922 \mathrm{x}^{3}-15.136 \mathrm{x}^{2}+29.826 \mathrm{x}+20.305, \mathrm{R}^{2}=0.9609 ;$ recipe $\mathrm{N}^{\circ} 2: \mathrm{y}=1.3161 \mathrm{x}^{3}-12.539 \mathrm{x}^{2}+26.149 \mathrm{x}+20.056, \mathrm{R}^{2}$ $=09917$; recipe $\left.\mathrm{N}^{\circ} 3: \mathrm{y}=1.3007 \mathrm{x}^{3}-13.195 \mathrm{x}^{2}+30.018 \mathrm{x}+20.069, \mathrm{R}^{2}=0.9976\right)$. 


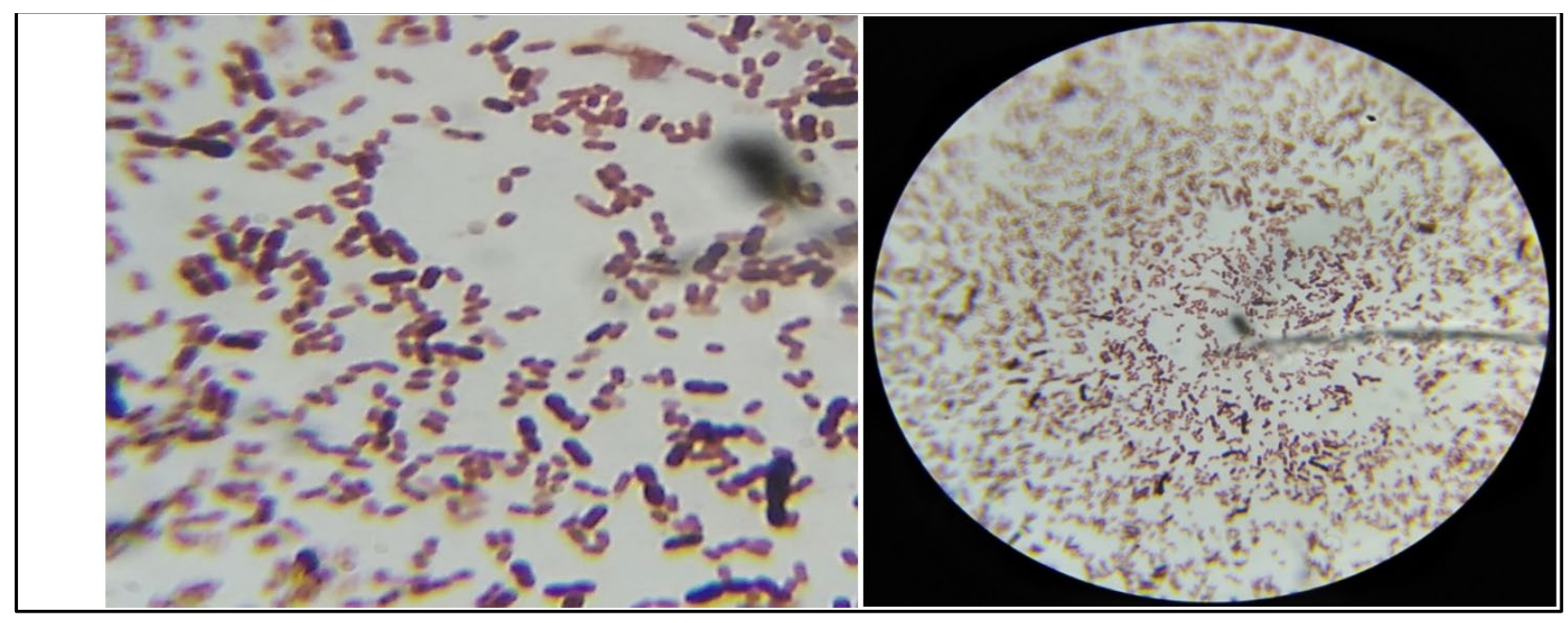

Figure 4. Images of "useful" microflora of brines (lactic acid bacteria, left, and micrococci) obtained from the mixtures studied (magnification of 1000 times).

To enhance the taste and aromatic characteristics of the finished product and expand the assortment of semi-finished products, we developed recipes for sprinkles from spices that covered the fish after salting (Table 3).

Table 3. Recipes for spices sprinkled coatings for semi-finished products.

\begin{tabular}{|c|c|c|c|c|}
\hline \multirow{2}{*}{ Brine components } & \multicolumn{4}{|c|}{ Rates of consumption [kg/100 $\mathrm{kg}$ of finished products] } \\
\hline & Recipe 1 & Recipe 2 & Recipe 3 & Recipe 4 \\
\hline Lemongrass & 2,5 & - & - & - \\
\hline Leaves of thyme & - & 1,0 & - & - \\
\hline Melissa & 2,0 & 1,5 & - & - \\
\hline Fresh garlic & - & 2,0 & - & - \\
\hline Coriander & - & - & 0,5 & - \\
\hline Rosemary & - & - & 2,5 & - \\
\hline Oregano & - & - & 2,0 & - \\
\hline $\begin{array}{l}\text { A mixture of dried Bulgarian } \\
\text { peppers }\end{array}$ & - & - & - & 4,5 \\
\hline Powder cardamom & - & - & - & 0,5 \\
\hline Ground black pepper & 0,5 & 0,25 & - & - \\
\hline Ground red pepper & - & 0,25 & - & - \\
\hline
\end{tabular}

Modern food technology is inseparable from the packaging process. It is known that fish is a rather complex delicate product, which has its own specifics that must be taken into account when selecting packaging and packaging equipment. The typical shelf life of chilled fresh fish is about $72 \mathrm{~h}$, with the use of protective atmosphere or in vacuum it is possible to increase the shelf life of fresh fish to 5 to 9 days (Cutter, 2006; Alfaro et al., 2013; Cyprian et al., 2013; Zahra et al., 2016).

Therefore, along with technological methods of pretreatment of fish raw materials, there is a need to select packaging materials, with the help of which it is possible to extend the shelf-life of chilled fish products. A progressive method of packaging today is the use of protective barrier films, which are produced from various polymeric materials with different degrees of protection against external environmental factors (Chouliara et al., 2007; Lyhs, et al., 2007; Cutter, 2006; Ranmeechai \& Photchanachai, 2017; Suh et al., 2017). Today, multilayer relief films of different manufacturers are available in the food industry.

Compared to single-layer polyethylene films, the Darfresh (R) packaging film, developed by the Swedish company Cryovac, is characterized by a more tight fit of the product ("second skin" effect) and additional 
barrier properties to oxygen and water vapor. Its use allowed to extend the shelf life of vacuum packed chilled semi-finished Japanese mackerel products. According to the results regarding the research, the KMAFAnM on the 20th day of storage did not exceed the permissible levels and ranged from $6.9 \times 10^{3}$ to $9.0 \times 10^{3} \mathrm{CFU} / \mathrm{g}$, depending on the recipes. Thus, the shelf life of culinary semi-finished products in Darfresh (R) packaging was 20 days at a temperature of $0{ }^{\circ} \mathrm{C}$ to $5{ }^{\circ} \mathrm{C}$ and an air humidity of $95 \%$ to $98 \%$.

The conducted study allowed to improve the technology for the production of chilled culinary semifinished products from Japanese mackerel. The use of salted media developed by us in technology allowed to improve the organoleptic and microbiological parameters of the finished products, and to reduce oxidative processes. The application of Darfresh (R) packaging film ensured the extension of the shelf life of chilled semi-finished products from Japanese mackerel to 20 days.

\section{Conclusions}

According to the results of the conducted studies, it could be determined that the preliminary aging of the mackerel in salting positively influenced the quality of the prepared semi-finished products. It has been experimentally found that injecting the Japanese mackerel with salting media improved the organoleptic parameters of the finished product. In the process of aging, the color of the fish improved, and the muscular tissue of the mackerel was lightened. In the process of salting, the fish could acquire a pleasant smell of brine compositions and spices. Regarding consistency, they became more succulent and less fibrous, even as the fibrous muscle tissue began to disapear. The taste became pleasant, depending on the formula with more or less pronounced sourness, with a hint of spices. The developed recipes compositions of salting media provided a faster glazing and ripening of the raw material comparing to the control sample. The conducted studies showed a decrease in the total number of microorganisms (KMAFAnM) in the process of aging in salting. Based on the results of the research, the rational duration of mackerel salting, injected with salting media, was 4 to $5 \mathrm{~h}$ at a temperature of $6{ }^{\circ} \mathrm{C}$ to $8{ }^{\circ} \mathrm{C}$. To enhance the taste and aromatic characteristics of the finished product and expand the range of semi-finished products, it is recommended to coat the fish after salting with sprinkles of spices. The use of Darfresh (R) thermoforming film for packaging allowed to fix the fish in the package, to ensure the attractiveness of the goods for the consumer due to its transparency. The film had additional barrier properties to oxygen and water vapor. Its use allowed to extend the shelf life of vacuum packed chilled culinary mackerel semi-finished products up to 20 days at a temperature of $0{ }^{\circ} \mathrm{C}$ to $5{ }^{\circ} \mathrm{C}$ and air humidity of $95 \%$ to $98 \%$.

An advanced technology for the production of chilled culinary mackerel semi-finished products ensures the production of high-quality products that meet consumer demand.

\section{References}

Alfaro, B., Hernandez, I., Balino-Zuazo, L., \& Barranco, A. (2013). Quality changes of Atlantic horse mackerel fillets (Trachurus trachurus) packed in a modified atmosphere at different storage temperatures. Journal of the Science of Food and Agriculture, 93(9), 2179-2187. PMid:23401147. http://dx.doi.org/10.1002/jsfa.6025

Ali, F., Abdel-Atty, N., \& Helmy, E. (2018). Improving the qvality and extending the shelf life of chilled fresh sausages using natural additives and their extracts. Journal of Microbiology, Biotechnology and Food Sciences, 7(6), 580-585.

Amariei, S., Poroch-Seriţan, M., Gutt, G., Oroian, M., \& Ciornei, E. (2016). Rosemary, thyme and oregano essential oils influence on physicochemical properties and microbiological stability of minced meat. Journal Of Microbiology, Biotechnology and Food Sciences, 6(1), 670-676. http://dx.doi.org/10.15414/jmbfs.2016.6.1.670-676.

Blagonravova, M. V., \& Gritsaenko, L. D. (2014). Clarification of the classification of salting methods. Bulletin of Kamchatka State Technical University, 28, 45-49.

Bogdanov, V. D., \& Saltanova, N. S. (2005). Technology of slightly salted herring pre-ripening. Journal of Fisheries, 1, 64-65.

Boland, M. J., Rae, A. N., Vereijken, J. M., Meuwissen, M. P. M., Fischer, A. R. H., van Boekel, M. A. J. S., Rutherfurd, S. M., Gruppen, H., Moughan, P. J., \& Hendriks, W. H. (2013). The future supply of animal-derived protein for human consumption. Trends in Food Science \& Technology, 29(1), 62-73. http://dx.doi.org/10.1016/j.tifs.2012.07.002

Bugakov, M. P., Glotova, I. A., Artemov, E. S., \& Pelevina, G. A. (2012). Local bioresources in the development of the market of fish preserves. Food Technology, 2-3, 27-28. 
Chouliara, E., Karatapanis, A., Savvaidis, I. N., \& Kontominas, M. G. (2007). Combined effect of oregano essential oil and modified atmosphere packaging on shelf-life extension of fresh chicken breast meat, stored at $4{ }^{\circ} \mathrm{C}$. Food Microbiology, 24(6), 607-617. PMid:17418312. http://dx.doi.org/10.1016/j.fm.2006.12.005

Cutter, C. N. (2006). Opportunities for bio-based packaging technologies to improve the quality and safety of fresh and further processed muscle foods. Meat Science, 74(1), 131-142. PMid:22062722. http://dx.doi.org/10.1016/j.meatsci.2006.04.023

Cyprian, O., Oduor-Odote, P., Lauzon, H., Martinsdyttir, E., \& Arason, S. (2013). Microbiological quality and shelf life of fresh packaged tilapia fillets stored under different chill temperatures. Journal of Microbiology, Biotechnology and Food Sciences, 4 , 2431-2455.

Dabrowski, W., Rozycka-Kasztelan, K., Czeszejko, K., \& Medrala, D. (2002). Microflora of low-salt herring II. The influence of sodium benzoate on microflora of low-salt herring. Electronic Journal of Polish Agricultural Universities Series Food Science and Technology, 5(2).

Dimova, V. V., Ershov, A. M., Grokhovskii, V. A., \& Ershov, M. A. (2006). Theoretical base of the process of salting the fish and calculating the duration of salting. Bulletin of MSTU, 6, 858-865.

Dixon, Z., Vanderzant, C., Acuff, G. R., Savell, J. W., \& Jones, D. K. (1987). Effect of acid treatment of beef strip loin steaks on microbiological and sensory characteristics. International Journal of Microbiology, 5(2), 181-186. http://dx.doi.org/10.1016/01681605(87)90035-3

Elgayyar, M., Draughon, F. A., Golden, D. A., \& Mount, J. R. (2001). Antimicrobial activity of essential oils from plants against selected pathogenic and saprophytic microorganisms. Journal of Food Protection, 64(7), 1019-1024. PMid:11456186. http://dx.doi.org/10.4315/0362-028X-64.7.1019

Estévez, M., Ramirez, R., Ventanas, S., \& Cava, R. (2007). Sage and rosemary essential oils versus BHT for the inhibition of lipid oxidative reactions in liver pate. $L W T, 40(1), 58-65$. http://dx.doi.org/10.1016/j.lwt.2005.07.010

Eurasian Economic Union - EAEU. (2017, January 9). On the safety of fish and fish products (EAEU TR 040/2016). Council of the Eurasian Economic Commission, Moscow. Retrieved in 2018, October 18, from http://docs.cntd.ru/document/420394425

European Union - EU. (2007). Commission Regulation (EC) No 1441/2007 of 5 December 2007, amending regulation no 2073/2005 on microbiological criteria for foodstuffs. Official Journal of the European Union, Brussels.

Falowo, A. B., Fayemi, P. O., \& Muchenje, V. (2014). Natural antioxidants against lipid-protein oxidative deterioration in meat and meat products: A review. Food Research International, 64, 171-181. PMid:30011637.

http://dx.doi.org/10.1016/j.foodres.2014.06.022

Françoise, L. (2010). Occurrence and role of lactic acid bacteria in seafood products. Food Microbiology, 27(6), 698-709. PMid:20630312. http://dx.doi.org/10.1016/j.fm.2010.05.016

Georgantelis, D., Ambrosiadis, I., Katikou, P., Blekas, G., \& Georgakis, S. A. (2007). Effect of rosemary extract, chitosan and atocopherol on microbiological parameters and lipid oxidation of fresh pork sausages stored at $4^{\circ} \mathrm{C}$. Meat Science, $76(1), 172-$ 181. PMid:22064204. http://dx.doi.org/10.1016/j.meatsci.2006.10.026

Gheisari, H. R., \& Ranjbar, V. R. (2012). Antioxidative and antimicrobial effects of garlic in ground camel meat. Turkish Journal of Veterinary and Animal Sciences, 36, 13-20.

Kaya, G. K., \& Basturk, O. (2015). Determination of some qualitative properties of marinated sea bream (Sparus Aurata L., 1758) during cold storage. Radio Engineering, 35(2), 347-353.

Kim, G. N., Kim, I. N., Safronova, T. M., \& Megeda, E. V. (2014). Sensory analysis of processed fish products and invertebrates. Tutorial. Saint-Petersburg: Lan Publishing.

Kolodyaznaya, V. S., \& Demchenko, V. A. (2010). The effect of complex lactate-containing food additives on the ripening and storage of preserves from frozen fish. Journal of Fisheries, 4, 49-51.

Lyhs, U., Lahtinen, J., \& Schelvis-Smit, R. (2007). Microbiological quality of maatjes herring stored in air and under modified atmosphere at 4 and $10^{\circ} \mathrm{C}$. Food Microbiology, 24(5), 508-516. PMid:17367684. http://dx.doi.org/10.1016/j.fm.2006.08.003

Molchanova, E. I., Udalova, L. P., \& Ponamareva, V. E. (2013). Features of the regional market for semi-finished meat products. Food Industries, 1, 72-74.

Morales, L. E., \& Higuchi, A. (2018). Is fish worth more than meat? - How consumers' beliefs about health and nutrition affect their willingness to pay more for fish than meat. Food Quality and Preference, 65, 101-109. http://dx.doi.org/10.1016/j.foodqual.2017.11.004

Naresh, K. M., \& Nayak, B. B. (2017). Bio-chemical composition, functional, and rheological properties of fresh meat from fish, squid, and shrimp: A comparative study. Journal International Journal of Food Properties, 20(1), 707-721.

Nehamkin, B. L., Porotikova, E. Yu., \& Stepanenko, E. I. (2015). Salted fish on the trading shelves: What is released and what is sold. In Proceedings of the $X$ international scientific- practical conference: Production of fish products: Problems, new technologies, quality. Kaliningrad.

Okpanachi, M. A., Yaro, C. A., \& Bello, O. Z. (2018). Assessment of the effect of processing methods on the proximate composition of Trachurus trachurus (Mackerel) sold in Anyigba Market, Kogi State. American Journal of Food Science and Technology, 6(1), 26-32.

Pieniak, Z., Verbeke, W., \& Scholderer, J. (2010). Health-related beliefs and consumer knowledge as determinants of fish consumption. Journal of Human Nutrition and Dietetics, 23(5), 480-488. PMid:20831707. http://dx.doi.org/10.1111/j.1365277X.2010.01045.X

Pohlman, F. W., Dias-Morse, P. N., Quilo, S. A., Brown, A. H., Crandall, P. G., Baublits, R. T., Story, R. P., Bokina, C., \& Rajaratnam, G. (2009). Microbial, instrumental color and sensory characteristics of ground beef processed from beef trimmings 
treated with potasium lactate, sodium metasilicate, peroxyacetic acid, or acidified sodium chlorite as single antimicrobial interventiions. Journal of Muscle Foods, 20(1), 54-69. http://dx.doi.org/10.1111/j.1745-4573.2008.00133.x

Ranmeechai, N., \& Photchanachai, S. (2017). Effect of modified atmosphere packaging on the quality of germinated parboiled brown rice. Food Science and Biotechnology, 26(2), 303-310. PMid:30263543. http://dx.doi.org/10.1007/s10068-017-0041-2

Schuldt, S., Raak, N., Jaros, D., \& Rohm, H. (2014). Acid-induced formation of soy protein gels in the presence of NaCl. LWT, 57(2), 634-639. http://dx.doi.org/10.1016/j.Iwt.2014.02.013

Smaoui, S., Ben Hlima, H., \& Ghorbel, R. (2012). The effects of sodium lactate and lactic acid combinations on the microbial, sensory, and chemical attributes of marinated chicken thigh. Poultry Science, 91(6), 1473-1481. PMid:22582309. http://dx.doi.org/10.3382/ps.2011-01641

Stepanenko, E. I., Andreev, M. P., \& Nehamkin, B. L. (2016). The use of food additives in the technology of molded fish products with intermediate humidity. Bulletin of KSTU, 42, 138-146.

Suh, S., Kim, Y. E., Shin, D., \& Ko, S. (2017). Effect of frozen-storage period on quality of American sirloin and mackerel (Scomber japonicus). Food Science and Biotechnology, 26(4), 1077-1084. PMid:30263639. http://dx.doi.org/10.1007/s10068017-0146-7

Topuz, O. K. (2016). Effects of marinating time, acetic acid and salt concentrations on the quality of little tunny fish (Euthynnus alletteratus) fillet. Journal of Food Processing and Preservation, 40(6), 1154-1163. http://dx.doi.org/10.1111/jfpp.12696

Uçak, I., \& Gökoğlu, N. (2017). Effect of high hydrostatic pressure on sensory quality of marinated herring (Clupea harengus). Journal of Food Processing and Preservation, 41(2), e12784.

Zahra, S. A., Butt, Y. N., Nasar, S., Akram, S., Qindeel, F. \& Ikram, J. (2016). Food packaging in perspective of microbial activity a review. Journal of Microbiology, Biotechnology and Food Sciences, 6(2), 752-757.

Zhang, Y., Chen, J., Qiu, J., Li, Y., Wang, J., \& Jiao, J. (2016). Intakes of fish and polyunsaturated fatty acids and mild-to-severe cognitive impairment risks: A doseeresponse meta-analysis of 21 cohort studies. The American Journal of Clinical Nutrition, 103(2), 330-340. PMid:26718417. http://dx.doi.org/10.3945/ajcn.115.124081 